\title{
INDUSTRIAL SOLID WASTE (WHITEWASH MUD) USE IN FOREST ROAD PAVEMENTS ${ }^{1}$
}

\author{
Carlos Cardoso Machado ${ }^{2}$, Reginaldo Sérgio Pereira ${ }^{3}$, Dario Cardoso de Lima², Carla Ribeiro Machado e \\ Portugal $^{4}$, José Maurício Machado Pires ${ }^{3}$, Gersonito da Silva Vieira ${ }^{5}$
}

\begin{abstract}
The objective of the present study was to evaluate the effects of industrial solid waste (whitewash mud) on geotechnical properties considering the following engineering parameters: California Bearing Ratio (CBR), Atterberg limits and Permeability test. Seven soil samples derived from Alagoinhas, Bahia - Brazil, were classified by the Transportation Research Board (TRB) system. Two were selected as having a great geotecnical potential classified as A-3 (0) and A-2-4 (0), whitewash mud contents $10 \%, 15 \%, 20 \%$ and $25 \%$ dry weight and medium compaction effort were studied in the laboratory testing program. The results indicated the soil denominated good gravel as being the most promising one, when stabilized with whitewash mud, reaching the best results with the dosage of 20 and $25 \%$ of whitewash mud.
\end{abstract}

Key Words: Forest road, industrial solid waste, whitewash mud, soil stabilization.

\section{UTILIZAÇÃO DO RESÍDUO SÓLIDO INDUSTRIAL (LAMA-DE-CAL) EM PAVIMENTOS DE ESTRADAS FLORESTAIS}

\begin{abstract}
RESUMO - O objetivo do presente estudo foi avaliar os efeitos do resíduo sólido industrial (lama-de-cal) nas propriedades geotécnicas de amostras de solo da região de Alagoinhas, BA, Brasil. Das sete amostras coletadas, apenas duas foram selecionadas, por apresentar maior potencial geotécnico. Utilizaram-se ensaios de caracterização, CBR e permeabilidade, cujos resultados indicaram que a amostra de solo denominada good gravel quando estabilizada com lama-de-cal, na dosagem de 20 e 25\%, foi a mais promissora.
\end{abstract}

Palavras-chave: Estrada florestal, resíduo sólido industrial, lama-de-cal, estabilização de solo.

\section{INTRODUCTION}

In many situations, soils in natural state do not present adequate geotechnical properties to be used as road service layers, therefore the importance of studying soil stabilization in order to adjust their geotechnical parameters to meet the requirements of technical specifications of the road construction industry. The problem in road supports is basically related to the type of soil to be used. When it is characterized as sand, it presents extreme conditions of the sandy soils, usually obtaining elevated support capacity under service conditions, if adequately confined laterally. On the other hand, the occurrence of unpaved road is generally associated with the presence of clay, claysilty-sandy soils and even silty-clay soils, because they show substantial loss of superficial particles under traffic and local climatic factors.

\footnotetext{
${ }^{1}$ Recebido para publicação em 27.8.2003 e aceito para publicação em 10.8.2004.

${ }^{2}$ FederalUniversity of Viçosa. <machado@ufv.br/declima@mail.ufv.br>.

${ }^{3}$ Federal University of Viçosa. <rpereira@buynet.com.br>.

${ }^{3}$ Federal University of Viçosa. < jmauricio@uaimail.com.br>.

${ }^{4}$ Federal University of Uberlandia. $<$ rsallesp@terra.com.br $>$.

${ }^{5}$ Federal University of Viçosa. <gersonitovieira@bol.com.br>.

Financial support: $\mathrm{CNPq} / \mathrm{FAPEMIG}$
} 
Considering the Brazilian experience and the costbenefit relation of road building contractors, the use of chemical stabilization and mechanical methods of soil stabilization for roads is common. Historically, cement and whitewash have been used in highways pavement, particularly in base and sub-base layers, usually 6$10 \%$ cement and 5-6\% whitewash (BRASIL, 1996). DNER is actually DNIT (Brazilian Highway Department). However, in forest roads, the costs associated with the use of these techniques can be considered impracticable. Thus, a low cost technological solution for the forest road sector could be the application of waste generated in production processes, used as chemical additives to improve soil geotechnical characteristics. This would meet the road technical constructive requirements as well as guarantee the disposal of industrial waste, many times harmful to the environment, confining it in controlled conditions under the highway structure. Whitewash mud, a pulp and paper industry sub-product, has great potential for this kind of use.

The objective of this study was to analyze, in laboratory, the geotechnical performance of whitewash mud-soil mixtures in forest road pavements, considering the following engineering parameters: $\mathrm{CBR}$, consistence limits and highway permeability tests.

\section{MATERIAL AND METHODS}

\subsection{Soil samples}

Seven soil samples, from Klabin-Bacell Company, Alagoinhas, Bahia, Brazil, have been characterized and classified geotechnically according to the system adopted by the Transportation Research Board (TRB). the most important samples had been identified in function of the collecting place as: a) Subgrade sand - samples collected under the forest road surface and; b) Good gravel - samples collected from a mine.

\subsection{Whitewash mud}

The potential of whitewash mud, derived from pulp and paper processing, was evaluated as chemical stabilizer for the soil samples, to be classified as a chemical stabilizer from a geotechnical point of view. Whitewash mud was used in its pure form, as the company disposes it of in the embankment.

R. Árvore, Viçosa-MG, v.28, n.4, p.547-551, 2004

\subsection{Soil samples collection}

The field procedures adopted for soil sample collection consisted in extraction, packing into plastic bags and transportation to the Geotechnical Laboratory of the Federal University of Viçosa. Then, the soil samples were dried to air, put through a $4,8 \mathrm{~mm}$ mesh sieve, determined the humidity, and stored in sealed up plastic bags. The preparation of deformed soil sample used in the geotechnical tests followed the recommendations of the Brazilian Association of Technical Standards (ABNT), according to procedure NBR 6457/86.

\subsection{Whitewash mud dosages}

The whitewash mud dosages were 10, 15, 20 and $25 \%$ of dry soil weight, chosen on the basis of preliminary tests.

\subsection{Laboratory tests}

The tests for soil sample characterization included the following determinations: sieve analysis (ABNT, 1984a), liquid limit (ABNT, 1984b), plastic limit (ABNT, 1984c) and soil particle specific mass determination (ABNT, 1984d). After this stage, a technical analysis of the results was carried out to define which soil samples could be considered representative to be used in stabilization processes and therefore in the determination of compaction, soil CBR, soil permeability and whitewash mud mixtures. The following indexes were determined for the selected samples: optimum compaction parameters (ABNT, 1986), in the medium energy effort AASHTO test; California Bearing Ratio - CBR (DNER, 1996); and permeability (HEAD, 1982). The sequence of execution for the compaction, CBR and permeability tests were: Soil as it is, dried to air humidity plus water - resting for 24 hours before compaction; Soil plus whitewash mud: addition of whitewash mud to the soil, with subsequent addition of water, and then sieving through a 4,8 $\mathrm{mm}$ mesh net, to reach homogenization of at least $80 \%$, and finally, initiation of compaction.

\section{3- RESULTS AND DISCUSSIONS}

\subsection{Classification and geotechnical characterization of soil}

Table 1 presents a summary of the results for the geotechnical characterization tests, as well as the 
respective classification of the soil samples from Alagoinhas, Bahia, Brazil, through the TRB process (BRASIL, 1996). Analyzing Table 1 according to the TRB recommendations, it is verified that the soil samples studied, except for the one called high subgrade collected at Klabin Farm, integrate the group of granular materials having potential for road building, foreseeing a good to excellent performance as material for subgrade in forest road pavement. The high subgrade sample fits the fine soil group of the related system of classification, showing a weak to poor performance as material for subgrade.

The analysis of the results presented in Table 1 also leads to the conclusion that the samples Subgrade sand and Good gravel, from the point of view of grain size and plasticity (NP for the first one, and IP equal to $6 \%$ for the second) can be considered representative of the set of soil tested and suitable to be used as component of the mixtures soil + whitewash mud. Figure 1 presents the grain size curves of these samples. It is observed in Table 1 that the grain sized fractions assigned as gravel, sand, silt and clay are related to the following diameters: 76 to $2 \mathrm{~mm}$ fraction gravel, 2 to $0,074 \mathrm{~mm}$ fraction sand, 0,074 to $0,005 \mathrm{~mm}$ fraction silt and under $0,005 \mathrm{~mm}$ fraction clay.

\subsection{Compaction and CBR tests for soil and whitewash mud mixtures}

Table 2 shows compaction, CBR and expansion measured in the CBR test of soil as it is and soil plus whitewash mud for the Subgrade sand and Good gravel samples. In the case of mixtures, it is noticed that there was a one-day cure period before performing the CBR test. The soil compaction parameters had little variation in optimum humidity and maximum specific mass in relation to the addition of different whitewash mud dosages. CBR values, for some whitewash mud contents, were superior to the ones of soil as it is, with the best results for Good gravel samples at the dosages of $20 \%$ and $25 \%$, with gains respectively in the order of $14 \%$ and $46 \%$.

However, it must be evidenced that the addition of whitewash to a soil is usually responsible for cationic exchange, flocculation and cementation as pozzolanic reactions. The first two are responsible for small immediate gains of mechanical resistance in the stabilized mixture, and the third for increasing mechanical resistance with time. Therefore, it must be considered the gain of soilwhitewash mixture resistance, separating mechanical resistance of cured mixture from mechanical resistance of uncured mixture. In this context, the parameters CBR and Expansion ${ }_{\mathrm{CBR}}$ presented in table 2 could be understood as corresponding to values for mechanical resistance of uncured mixture, foreseeing that there will be a trend of significant increase in CBR and decrease in Expansion ${ }_{\mathrm{CBR}}$ values with time.

Table 3 summarizes the technical requirements for dimensioning flexible pavements used by the Brasil (1996), which it is based on the results of soil characterization and $\mathrm{CBR}$ tests. In Alagoinhas, Bahia, Brazil, where there is a deficiency of road construction materials and the solicitation number for the standard axle ( 8.2 tons) can be estimated as equal or inferior to $5 \times 10^{6}$, it is known that the DNER recommends the use of base layers with CBR equal or below $60 \%$ and

Table 1 - Results for sieve analysis, Atterberg limits (LL, LP and IP) and TRB classification Tabela 1 - Resultados dos ensaios de caracterização e limites de Atterberg ( $L L, L P$ e IP)

\begin{tabular}{|c|c|c|c|c|c|c|c|c|c|}
\hline $\begin{array}{l}\text { Sample } \\
\text { Soil } \\
\end{array}$ & $\begin{array}{c}\text { Gravel } \\
(\%) \\
\end{array}$ & $\begin{array}{c}\text { Sand } \\
(\%)\end{array}$ & $\begin{array}{l}\text { Silt } \\
(\%) \\
\end{array}$ & $\begin{array}{l}\text { Clay } \\
(\%)\end{array}$ & $\begin{array}{l}\text { LL } \\
(\%) \\
\end{array}$ & $\begin{array}{l}\text { LP } \\
(\%) \\
\end{array}$ & $\begin{array}{l}\text { IP } \\
(\%) \\
\end{array}$ & $\begin{array}{l}\text { Ydmax. } \\
\left(\mathrm{kN} / \mathrm{m}^{3}\right)\end{array}$ & $\begin{array}{r}\text { Classification } \\
\text { TRB } \\
\end{array}$ \\
\hline \multicolumn{10}{|l|}{ Farm KLB } \\
\hline Subgrade sand-1 & - & 85 & 13 & 2 & - & - & NP & 26.5 & A3 $(0)$ \\
\hline Subgrade sand-2 & - & 78 & 20 & 2 & - & - & NP & 26.0 & A3 $(0)$ \\
\hline High Subgrade & - & 59 & 16 & 25 & 27 & 17 & 10 & 26.5 & A4 (0) \\
\hline Good gravel & 76 & 16 & 3 & 5 & 21 & 15 & 6 & 27.5 & A-2-4 (0) \\
\hline Poor gravel & 50 & 26 & 10 & 14 & 34 & 22 & 11 & 27.0 & A-2-6 (4) \\
\hline \multicolumn{10}{|l|}{ Farm Matinha } \\
\hline Subgrade & - & 76 & 3 & 21 & - & - & NP & 26.0 & A3 (0) \\
\hline Gravel & 32 & 24 & 21 & 23 & 20 & 14 & 6 & 27.0 & A-2-4 (0) \\
\hline
\end{tabular}


Expansion $_{\mathrm{CBR}}$ below $0.5 \%$. Therefore, considering the data from Table 2, none of the tested mixtures met either requirement. That is why this material it is not recommended as base layer, even it has been verified significant gains of mechanical resistance in the mixtures Good gravel plus whitewash mud (20\%:25\%). It is worth mentioning that Sand subgrade and Good gravel, in natural state, meet the requirements for sub-base materials, since it presents CBR index above 20\% (26,4 and $35,5 \%$, respectively) and below $1 \%$ expansion.

\subsection{Results of the permeability tests for soil and whitewash mud mixture}

Table 4 presents the values of hydraulic conductivity coefficients of the body-of-test molded soil, Subgrade

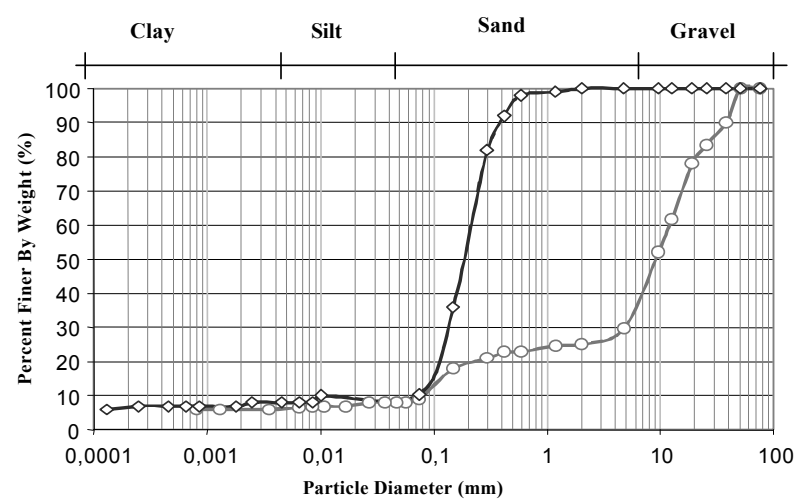

Figure 1 - Particle size distribution of Subgrade sand and Good gravel.

Figura 1 - Distribuição de tamanho de partícula de areia de Subgrade e pedregulho Bom. sand, Good gravel, mixtures of Subgrade sand $+20 \%$ whitewash mud and Good gravel $+25 \%$ whitewash mud, compacted in American Association Highway and Transportation Officials (AASHTO) medium energy, $8.1 \%$ and $11.0 \%$ humidity contents respectively. It is observed in the case of Subgrade sand that there is no significant changes in the hydraulic conductivity values and the emptiness index of the soil samples when compared with soil stabilized with whitewash mud. However, it has occurred variation of $10 \%$ in the hydraulic conductivity and 63\% in the emptiness index of Good gravel after the stabilization with whitewash mud. It is also noteworthy that the permeability coefficients of the soil studied fit into the characteristic fraction silt, by Pinto (2000).

Table 3 - DNIT technical requirements to be used as layers of reinforcement, sub-base and base of flexible road floors

Tabela 3 - Recomendações técnicas do DNIT para dimensionamento de pavimentos rodoviários flexiveis

\begin{tabular}{lc}
\hline Pavement layer & Dimensioning Method of DNER(1996) \\
\hline Reinforcement & CBR $>$ CBR SUBGRADE \\
Expansion $\leq 2 \%$ \\
CBb base \\
Expansion $\leq 1 \%$ \\
Base & Index Group (IG) $=0$ \\
& CBR* $\geq 80 \%$ \\
& Expansion $\leq 0,5 \% ;$ LL $\leq 25 \% ;$ IP $\leq 6 \%$ \\
if LL $>25 \%$ e IP $>6 \%$ then Sand \\
Equivalent $($ EA $) \geq 30 \%$
\end{tabular}

* DNER (1971): in the case of $\mathrm{N} \leq 5 \times 10^{6}$ of the standard axle of 8.2 tones, it could be used material with CBR $\geq 60 \%$.

Table 2 - Geotechnical parameters: moisture content (Wot), maximum specific dry gravity (Ydmax), CBR and expansion CBR (\%), for the period of one-day cure before performing the CBR test

Tabela 2 - Parâmetros geotécnicos: umidade, densidade máxima e expansão, no período de um dia de cura antes dos ensaios de $C B R$

\begin{tabular}{|c|c|c|c|c|}
\hline Soil Sample & $\mathrm{W}_{\mathrm{o} t}(\%)$ & $\mathrm{Y}_{\text {dmáx }}\left(\mathrm{kN} / \mathrm{m}^{3}\right)$ & CBR (\%) & Expansion $_{\mathrm{CBR}}(\%$ \\
\hline Subgrade sand & 8.10 & 16.99 & 26.40 & 0.04 \\
\hline Subgrade sand $+10 \%$ Whitewash Mud & 8.20 & 16.30 & 12.50 & 0.10 \\
\hline Subgrade sand $+15 \%$ Whitewash Mud & 10.00 & 16.50 & 11.30 & 0.16 \\
\hline Subgrade sand $+20 \%$ Whitewash Mud & 11.40 & 17.40 & 27.30 & 0.26 \\
\hline Subgrade sand $+25 \%$ Whitewash Mud & 10.80 & 16.90 & 19.40 & 0.48 \\
\hline Good gravel & 11.05 & 18.41 & 35.50 & 1.03 \\
\hline Good gravel $+10 \%$ Whitewash Mud & 10.40 & 16.60 & 23.00 & 0.21 \\
\hline Good gravel $+15 \%$ Whitewash Mud & 11.20 & 16.05 & 27.00 & 0.22 \\
\hline Good gravel $+20 \%$ Whitewash Mud & 11.40 & 18.30 & 40.50 & 0.88 \\
\hline Good grave1 $+25 \%$ Whitewash Mud & 1080 & 18.45 & 52.00 & 0.92 \\
\hline
\end{tabular}

R. Árvore, Viçosa-MG, v.28, n.4, p.547-551, 2004 
Table 4 - Values of the hydraulic conductivity coefficient, $K_{20}(\mathrm{~cm} / \mathrm{s})$ for Subgrade sand, Good gravel and Subgrade sand $+20 \%$ whitewash mud, and Good gravel $+25 \%$ of whitewash mud soil mixtures compacted in medium energy

Tabela 4 - Valores dos coeficientes de condução hidráulica de amostras de solo e misturas solo-lama-de-cal a 25\% compactada na energia intermediária

\begin{tabular}{lcccc}
\hline Soil Sample & Hydraulic Conductivity Coefficient, $\mathrm{K}_{20}(\mathrm{~cm} / \mathrm{s})$ & \multicolumn{2}{c}{ Void Ratio $(\%)$} \\
\hline & Soil at it is & Soil-Whitewash Mud & Soil at it is & Soil-Whitewash Mud \\
Good gravel & $2.6 \times 10^{-4} \mathrm{~cm} / \mathrm{s}$ & $1.1 \times 10^{-3} \mathrm{~cm} / \mathrm{s}$ & 0.27 & 0.44 \\
Subgrade sand & $4.2 \times 10^{-4} \mathrm{~cm} / \mathrm{s}$ & $3.8 \times 10^{-4} \mathrm{~cm} / \mathrm{s}$ & 0.56 & 0.50 \\
\hline
\end{tabular}

\section{CONCLUSIONS}

The best effect of whitewash mud on soil mechanical characteristics occurred with $20 \%$ and $25 \%$ whitewash mud dosages for Good gravel, with CBR values of 40 and 53\%, respectively. It is also observed the occurrence of small or insignificant variation in hydraulic conductivity coefficients of the mixtures in comparison with soils as they are. The present study on the whitewash mud addition "in natura" at maximum dosage of $25 \%$ demonstrated its potential to be used as chemical soil stabilizer, considering the one-day period of cure used in this work. Certainly, greater mechanical resistance gains can be expected for larger cure periods. It is therefore clear that better results can be obtained with a deeper study of the soil/whitewash mud reactivity, but taking into account the variable cure period for at least 7 and 28 days, and the possibility of product improvement by high temperature thermal treatments.

\section{REFERENCES}

ASSOCIAÇÃO BRASILEIRA DE NORMAS TÉCNICAS - ABNT. NBR 7181/84 Solo; análise granulométrica. Rio de Janeiro: 1984a. 13p.
ASSOCIAÇÃO BRASILEIRA DE NORMAS TÉCNICAS - ABNT. NBR 6459/84 Solo; determinação do Limite de Liquidez. Rio de Janeiro: 1984b. 6p.

ASSOCIAÇÃO BRASILEIRA DE NORMAS TÉCNICAS - ABNT. NBR 7180/84 Solo; determinação do Limite de Plasticidade. Rio de Janeiro: 1984c. 3p.

ASSOCIAÇÃO BRASILEIRA DE NORMAS TÉCNICAS - ABNT. NBR 6508/84 Solo; determinação da massa específica aparente. Rio de Janeiro: 1984d. 8p.

ASSOCIAÇÃO BRASILEIRA DE NORMAS TÉCNICAS - ABNT. NBR 7182/86 Solo; ensaio de compactação. Rio de Janeiro: 1986. 10p.

BRASIL. Ministério dos Transportes. DNER. Manual de pavimentação. 2 ed. Rio de Janeiro: 1996. 320p.

HEAD, K. H. Manual of soil laboratóry testing, permeability, shear strength and compressibility tests. New York: Halsted Press Book, 1982. v. 2. p. 335-747.

PINTO, C.S. Curso básico de mecânica dos solos. São Paulo: 2000. 347p. 